\title{
PENGARUH BUDAYA ORGANISASI TERHADAP KINERJA PEGAWAI PADA KANTOR KECAMATAN BUKIT KEMUNING DI LAMPUNG UTARA
}

\author{
Fahrizi \\ Fakultas Ekonomi Universitas Sang Bumi Ruwa Jurai \\ fahrizi@fe.saburai.ac.id
}

\begin{abstract}
Abstrak. Organisasi merupakan sebuah sistem dan kegiatan manusia yang bekerja sama untuk mencapai beberapa tujuan umum melalui pembagian pekerjaan dan fungsi melalui tanggung jawab. Budaya organisasi adalah satu wujud anggapan yang dimiliki, diterima secara implisit oleh kelompok dan menentukan bagaimana kelompok tersebut merasakan, memikirkan, dan bereaksi terhadap lingkungannya yang beraneka ragam. Dalam setiap organisasi, budaya kerja selalu diharapkan baik karena baiknya budaya kerja akan berhubungan dengan berhasil atau tidaknya tujuan organisasi dicapai. Meningkatkan kinerja organisasi dalam suatu instansi secara keseluruhan harus dimulai dari meningkatkan kinerja individu tiap pegawai dalam instansi. Kinerja pegawai memiliki potensi besar menjadi competitive advantage yang sulit ditiru, sebagai mana yang menjadi paradigma dalam Human Capital Management.Tujuan Penelitian ini adalah untuk mengetahui pengaruh budaya organisasi terhadap kinerja pegawai pada Kecamatan Bukit Kemuning di Lampung Utara. Metode yang penulis gunakan menggunakan data primer dan data sekunder. Penelitian yang akan dilaksanakan jenis Penelitian Deskriptif. Jenis penelitian ini adalah penelitian yang bermaksud membuat pemaparan secara sistimatis, faktual, dan akurat mengenai fakta-fakta dan sifat-sifat populasi tertentu. Penelitian ini menggunakan 46 responden penelitian. Ada dua variabel dalam penelitian ini yaitu : Variabel bebas $(\mathrm{X})$ dan variabel terikat dimana Budaya Organisasi $(\mathrm{X})$, sebagai variabel bebas dan Kinerja Pegawai (Y) sebagai variabel terikat. Dari hasil pengolahan data telah berhasil ditemukan jawaban hipotesis yakni sebagai berikut; terdapat pengaruh Budaya Organisasi (X) terhadap Kinerja Pegawai (Y), dengan tingkat pengaruh (R-square) sebesar 61,07\% yang berarti Budaya Organisasi memberikan pengaruh sebesar 61,07\% dan sisanya 38,93\% dipengaruhi oleh faktor lain.
\end{abstract}

Kata kunci: Budaya Organisasi, Kinerja Pegawai

\section{PENDAHULUAN}

Organisasi merupakan sebuah sistem dan kegiatan manusia yang bekerja sama untuk mencapai beberapa tujuan umum melalui pembagian pekerjaan dan fungsi melalui tanggung jawab. Sebuah organisasi membutuhkan manusia sebagai sumber daya pendukung utama untuk mencapai tujuan yang telah ditetapkan. Sumber Daya Manusia (SDM) yang berkualitas akan turut memajukan suatu organisasi pemerintahan sebagai suatu wadah peningkatan kinerja.

Era globalisasi saat ini dan dalam kondisi masyarakat sekarang, seringkali ditemukan beberapa masalah yang menyebabkan banyak organisasi atau instansi mengalami kegagalan, baik yang disebabkan oleh ketidakmampuan beradaptasi dengan kemajuan teknologi maupun yang disebabkan oleh kurang baiknya hasil kerja dari sumber daya manusia yang ada pada organisasi atau instansi tersebut, padahal harus diakui manusia adalah faktor penting yang turut menentukan keberhasilan suatu organisasi atau instansi.

Keberhasilan suatu organisasi atau instansi sangat ditentukan oleh kegiatan pendayagunaan sumber daya manusia yaitu orang-orang yang menyediakan tenaga, bakat kreativitas dan semangat bagi 
organisasi atau instansi serta memegang peranan penting dalam fungsi operasional organisasi atau instansi. Organisasi atau instansi tidak mungkin terlepas dari tenaga kerja manusia, walaupun aktivitas organisasi atau instansi itu telah mempunyai modal yang cukup besar dan teknologi modern, sebab bagaimanapun majunya teknologi tanpa ditunjang oleh manusia sebagai sumber dayanya maka tujuan organisasi atau instansi tidak akan tercapai, dengan demikian maka sumber daya manusia sangat penting untuk diberikan arahan dan bimbingan dari manajemen organisasi atau instansi pada umumnya dan manajemen sumber daya manusia pada khususnya.

Kinerja pegawai adalah perilaku nyata yang ditampilkan setiap pegawai sebagai prestasi kerja yang dihasilkan sesuai dengan perannya dalam organisasi (Rivai, 2009:309). Pada setiap orang yang bekerja atau dalam suatu kelompok kerja, kinerja selalu diharapkan bisa senantiasa baik kualitas dan kuantitasnya. Untuk mendapatkan hasil itu sendiri haruslah didukung dengan penetapan tujuan dan diawali dengan perencanaan kerja yang rasional. Maksud penetapan tujuan kinerja adalah menyusun sasaran-sasaran yang berguna tidak hanya sebagai pedoman mencapai tujuan, tetapi juga bisa menjadi sarana evaluasi kinerja pada akhir periode dan untuk mengelola keadaan pasca kerja selama periode tersebut (Setiyawan dan Waridin, 2010:184).

Meningkatkan kinerja organisasi dalam suatu instansi secara keseluruhan harus dimulai dari meningkatkan kinerja individu tiap pegawai dalam instansi. Kinerja pegawai memiliki potensi besar menjadi competitive advantage yang sulit ditiru, sebagai mana yang menjadi paradigma dalam Human Capital Management. Saat ini sumber daya manusia tidak lagi dianggap sebagai objek pelaksana perintah dan kebijakan perusahaan semata, tapi lebih sebagai subjek atau perilaku yang turut menentukan kelangsungan suatu perusahaan atau organisasi. Setiap organisasi akan selalu berusaha meningkatkan kinerja pegawai, dengan harapan apa yang menjadi tujuan perusahaan dapat tercapai dan menjadi lebih baik dari tahun ke tahunnya.

Manfaat dari penerapan budaya kerja yang baik : meningkatkan jiwa gotong royong, meningkatkan kebersamaan, saling terbuka satu sama lain, meningkatkan jiwa kekeluargaan, meningkatkan rasa kekeluargaan, membangun komunikasi yang lebih baik, meningkatkan produktivitas kerja, serta tanggap dengan perkembangan dunia luar, dan lain-lain.

Keberhasilan pelaksanaan program budaya kerja antara lain dapat dilihat dari peningkatan tanggung jawab, peningkatan kedisiplinan dan kepatuhan pada norma/aturan, terjalinnya komunikasi dan hubungan yang harmonis dengan semua tingkatan,peningkatan partisipasi dan kepedulian, peningkatan kesempatan untuk pemecahan masalah serta berkurangnya tingkat kemangkiran dan keluhan.

PNS sebagai aparatur pemerintah memiliki peranan yang sangat strategis dalam melaksanakan dan mengembangkan tugas umum pemerintah, seperti pelayanan publik secara menyeluruh. Di dalam menegakkan Kinerja PNS secara menyeluruh upaya pemerintah adalah dengan menetapkan Undang- Undang Nomor 8 Tahun 1974 yang dirubah dengan Undang- Undang Nomor 43 Tahun 1999 tentang Pokok- Pokok Kepegawaian selanjutnya PNS diatur dalam Peraturan Pemerintah Nomor 53 tahun 2010. Pembinaan pegawai ini diarahkan kepada kesejahteraan dan peningkatan kesejahteraan berdasarkan sistem karir dan sistem prestasi kerja secara berencana, terarah dan terpadu. Salah satu upaya pembinaan PNS adalah dengan pendidikan 
dan pelatihan, pengembangan karir, pembinaan Kinerja kerja.

Berdasarkan data dan uraian di atas, maka penulis tertarik untuk menulis skripsi dengan judul : " Pengaruh Budaya Organisasi Terhadap Kinerja Pegawai Pada Kantor Kecamatan Bukit Kemuning di Lampung Utara."

\section{KAJIAN TEORI}

\section{Pengertian Budaya Organisasi}

Budaya berasal dari bahasa sansakerta "budhayah" sebagai bentuk jamak dari kata dasar "budhi" yang artinya akal atau segala sesuatu yang berkaitan dengan akal pikiran, nilai-nilai dan sikap mental (Kompas, 2007 ; 3). Budidaya berarti memberdayakan budi sebagaimana dalam bahasa Inggris di kenal sebagai culture (latin - cotere) yang semula artinya mengolah atau mengerjakan sesuatu kemudian berkembang sebagai cara manusia mengaktualisasikan nilai (value), karsa (creativity), dan hasil karyanya (performance). Budaya dapat juga diartikan sebagai keseluruhan usaha rohani dan materi termasuk potensi-potensi maupun keterampilan masyarakat atau kelompok manusia. Budaya selalu bersifat sosial dalam arti yaitu penerusan tradisi sekelompok manusia yang mana dari segi materialnya dialihkan secara historis dan diserap oleh generasi-generasi menurut "nilai" yang berlaku. Nilai disini adalah ukuran-ukuran yang tertinggi bagi perilaku manusia.

\section{Ciri-Ciri Budaya Organisasi}


prestasi kerja yang diinginkan bagi pegawai, atasan dan organisasi secara umum.

Kinerja sebagai fungsi interaksi antara kemampuan atau ability (A), motivasi atau motivation (M) dan kesempatan atau opportunity (O), yaitu kinerja $=f(\mathrm{~A} \times \mathrm{M} \times \mathrm{O})$. Artinya: kinerja merupakan fungsi dari kemampuan, motivasi dan kesempatan (Robbins: 2013).

Menurut Robbins (2013:100) ada tiga faktor yang mempengaruhi kinerja :

1. Kemampuan fisik, mental pengetahuan, dan keterampilan.

2. Motivasi, yaitu kemampuan individu untuk mengeluarkan energi yang diperlukan untuk mencapai tujuan.

3. Kesempatan, atau opportunity yaitu kesempatan bagi individu untuk menunjukkan kinerjanya.

Menurut Mangkunegara (2010:6), faktor-faktor yang mempengaruhi kinerja dipengaruhi oleh 3 faktor, yaitu:

1. Faktor Kemampuan (job ability)

Kemampuan anggota tidak sama ada yang punya kemampuan tinggi atau sebaliknya berkemampuan rendah. Kemampuan diperoleh dari bakat dan pendidikan yang pernah diterimanya

2. Faktor Keterampilan (skill)

Keterampilan diperoleh dari pendidikan atau Pelatihan serta pengalaman kerja.

3. Faktor Pelatihan (job motivation)

Pelatihan lebih dipengaruhi oleh keinginan dan tujuan hidup serta lingkungan kerja sehari-hari yang selalu mempengaruhinya baik itu bersifat positif maupun negatif.

\section{METODE PENELITIAN}

\section{Objek Penelitian}

Dalam penelitian ini yang menjadi Objeknya adalah Kantor Kecamatan Bukit
Kemuning di Lampung Utara. Instansi ini terletak di Jl. Raya Kotabumi No. 34 Bukit Kemuning, Kotabumi, Kabupaten Lampung Utara, Lampung 34517. Pelaksanaan penelitian mulai bulan Maret sampai Agustus 2019.

\section{Metode dan Teknik Pengumpulan Data}

Dalam penelitian ini jenis data yang diperlakukan adalah :

a. Data Primer

Pengumpulan data primer dilakukan melalui survey ke lapangan secara langsung yang disertai dengan wawancara secara terbuka yang dilakukan dengan pegawai pada Kantor Kecamatan Bukit Kemuning di Lampung Utara.

b. Data Sekunder

Mencatat data-data yang dipublikasikan Kantor Kecamatan Bukit Kemuning di Lampung Utara dalam bentuk aplikasi dilapangan yang sifatnya berkala (time series).

\section{Sampel dan Populasi}

Penulisan ini menggunakan metode sensus. Menurut Suharsimi Arikunto (2008) apabila objek penelitian kurang dari 100 maka lebih baik diambil semua, selanjutnya jika jumlah lebih dari 100 maka dapat diambil antara $10-15$ persen. Menurut data yang ada jumlah pegawai di Kantor Kecamatan Bukit Kemuning di Lampung Utara dengan jumlah populasi 46 responden.

\section{Metode Analisis Data}

Untuk pengolahan data dalam bentuk tabulasi hasil jawaban responden kemudian dilakukan analisis data melalui metode analisis secara kualitatif dan analisis kuantitatif. 
Analisis kualitatif dilakukan dengan cara menggunakan beberapa teori manajemen sumber daya manusia khususnya mengenai pengaruh budaya organisasi terhadap kinerja pegawai pada Kantor Kecamatan Bukit Kemuning di Lampung Utara dan melalui data dari pengisian kuesioner pegawai pada Kantor Kecamatan Bukit Kemuning di Lampung Utara.

Analisis Kuantitatif yang dilakukan berdasarkan data primer yang diperoleh dari penyebaran instrument (daftar pertanyaan) kepada sampel, dan untuk mengetahui pengaruh dari variabel bebas (independen variabel) terhadap variabel terikat (dependen variabel).

Persamaan Regresi Linear Sederhana Menentukan persamaan regresi linear sederhana dengan rumus :

$$
Y=a+b X+e
$$

Dimana :

$$
\begin{array}{ll}
\mathrm{Y} & =\text { Kinerja Pegawai } \\
\mathrm{a} & =\text { Konstanta } \\
\mathrm{b} & =\text { Koefisien regresi X } \\
\mathrm{X} & =\text { Budaya Organisasi } \\
\mathrm{e} & =\text { Faktor kesalahan / Eror Team }
\end{array}
$$

( Sugiyono , $2008: 230$ )

Untuk menguji secara hipotesis secara parsial digunakan Uji $t$ dengan rumus :

$$
t_{\text {hitung }}=r \sqrt{\frac{n-2}{1-r^{2}}}
$$

Dimana :

$$
\begin{array}{ll}
\mathrm{t} \text { hitung } & =\text { Nilai } \mathrm{t} \\
\mathrm{r} & =\text { Koefisien Korelasi } \\
\mathrm{n} & =\text { Jumlah responden }
\end{array}
$$

( Sugiyono, $2008: 230$ )

Kriteria untuk Uji t adalah sebagai berikut :

1. Jika $\mathrm{t}$ hitung $>\mathrm{t}$ tabel maka $\mathrm{Ha}$ diterima dan Ho ditolak.

2. Jika $\mathrm{t}$ hitung $\leq \mathrm{t}$ tabel maka Ha ditolak dan Ho diterima.
Taraf signifikan dalam penelitian ini digunakan $\alpha=0,05$ atau 5\%.

Yang dimaksud dengan Hipotesis nol (Ho) dan Hipotesis alternatif (Ha) adalah :

1. $\mathrm{Ho}=\mathrm{r} 1 \leq 0=$ Berarti tidak ada pengaruh antara budaya organisasi terhadap kinerja pegawai

2. $\mathrm{Ha}=\mathrm{r} 1>0=$ Berarti ada pengaruh antara budaya organisasi terhadap kinerja pegawai

Berdasarkan dari pengertian diatas, maka koefisien determinasi merupakan bagian dari keragaman total dari variabel tak bebas yang dapat diperhitungkan oleh keragaman variabel bebas dihitung dengan koefisien determinasi dengan asumsi dasar faktor-faktor lain di luar variabel dianggap tetap atau konstan. Untuk mengetahui nilai koefisien determinasi, maka dapat dihitung dengan menggunakan rumus (Sugiyono, 2010):

$$
K D=r 2 \times 100 \%
$$

Dimana :

$\mathrm{KD}=$ Koefisien Determinan

$r=$ Kuadrat Koefisien Korelasi

\section{HASIL DAN PEMBAHASAN}

\section{Analisis Kuantitatif}

Untuk mengetahui besarnya pengaruh antara Budaya Organisasi terhadap kinerja pegawai dapat dihitung dengan rumus Koefisien Determinasi (KD), yaitu:

$$
\begin{gathered}
K D=r 2 \times 100 \% \\
=0,78152 \times 100 \% \\
=0,6107422 \times 100 \% \\
=61,07 \%
\end{gathered}
$$


Dengan demikian Budaya Organisasi terhadap kinerja pegawai pada Kecamatan Bukit Kemuning di Lampung Utara mempunyai pengaruh $61,07 \%$ dan sisanya sebesar $38,93 \%$ dipengaruhi oleh faktor lain.

Untuk mengetahui apakah hipotesis yang diajukan atau tidak, untuk itu penulis menggunakan uji $t$, dimana diperoleh $r$ sebesar 0,51 maka nilai $\mathrm{t}$ hitung adalah sebagai berikut :

t tes $=r \sqrt{\frac{n-2}{1-r^{2}}}$

t tes $=0,7815 \sqrt{\frac{46-2}{1-(0,7815)^{2}}}$

t tes $=0,7815 \sqrt{\frac{44}{1-0,610}}$

t tes $=0,7815 \sqrt{\frac{44}{0,739}} t=0,7815 \times 7,538$

Dari perhitungan di atas dapat diperoleh $\mathrm{r}$ hitung sebesar $\mathrm{t}=3,85$ sedangkan $r_{\text {tabel }}$ pada taraf signifikan atau $\alpha 0,05$ sebesar $\mathrm{t}=2,021$ dan $\mathrm{t}_{\text {tabel }}$ pada taraf signifikan $1 \%$ atau $\alpha$ sebesar 2,704, maka dengan demikian $\mathrm{t}$ hitung lebih besar dari $\mathrm{t}$ tabel.

\begin{tabular}{|l|l|}
\hline Besarnya Nilai & Interpretasi \\
\hline Antara $0,800-1,000$ & Sangat Tinggi \\
\hline Antara $0,600-0,800$ & Tinggi \\
\hline Antara $0,400-0,600$ & Sedang \\
\hline Antara $0,200-0,400$ & Rendah \\
\hline Antara $0,000-0,200$ & Sangat Rendah \\
\hline
\end{tabular}

Sumber : Suharsimi Arikunto, 2009

Maka didasarkan dengan ketentuan dengan penerimaan dan penolakan hipotesis yang kemungkinan sebelumnya, yaitu:

1. Ho ditolak jika ternyata thitung lebih besar dari tabel.

2. Ho diterima jika ternyata $t_{\text {hitung }}$ lebih kecil dari $t_{\text {tabel }}$
Berdasarkan ketentuan tersebut, maka hipotesis nihil (Ho) ditolak karena $\mathrm{t}$ hitung $=3,85$ lebih besar dari $\mathrm{t}$ tabel $=$ 2,021. Hal ini berarti bahwa terdapat hubungan yang positif antara Budaya Organisasi terhadap kinerja pegawai.

Dari uraian tersebut di atas dapat disimpulkan bahwa, hipotesis yang dipergunakan dalam penelitian ini adalah Budaya Organisasi mempunyai pengaruh yang positif dalam usaha meningkatkan kinerja pegawai pada Kecamatan Bukit Kemuning di Lampung Utara dapat diterima.

Berdasarkan hasil penelitian di atas, maka diperoleh Koefisien Determinasi Budaya Organisasi terhadap Kinerja Pegawai adalah sebagai berikut :

Koefisien Determinasi Budaya Organisasi terhadap Kinerja Pegawai.

Model Summary

\begin{tabular}{|l|l|l|l|l|}
\hline Model & & R Square & $\begin{array}{l}\text { Adjusted } \\
\text { Square }\end{array}$ & $\begin{array}{l}\text { Std. Error of the } \\
\text { Estimate }\end{array}$ \\
\hline 1 & $0,690 \mathrm{a}$ & 0,6107 & 0,458 & 2,94221 \\
& & & & \\
& & & & \\
& & & & \\
\hline
\end{tabular}

Koefisien Determinasi $(\mathrm{KD})=\mathrm{R} 2=$ $0,6902=0,6107=0,6107 \times 100 \%=$ $61,07 \%$. Dapat disimpulkan bahwa variabel Budaya Organisasi (X) menjelaskan variasi perubahan variabel Kinerja Pegawai (Y) sebesar 61,07\%, sedangkan sisanya dijelaskan oleh faktor lain yang tidak dikaji dalam penelitian ini.

Berdasarkan hasil penelitian, maka diperoleh data pengaruh Budaya Organisasi (X) terhadap Kinerja Pegawai (Y) sebagai berikut :

Uji Hipotesis Pengaruh Budaya Organisasi terhadap Kinerja Pegawai

Coefficientsa 


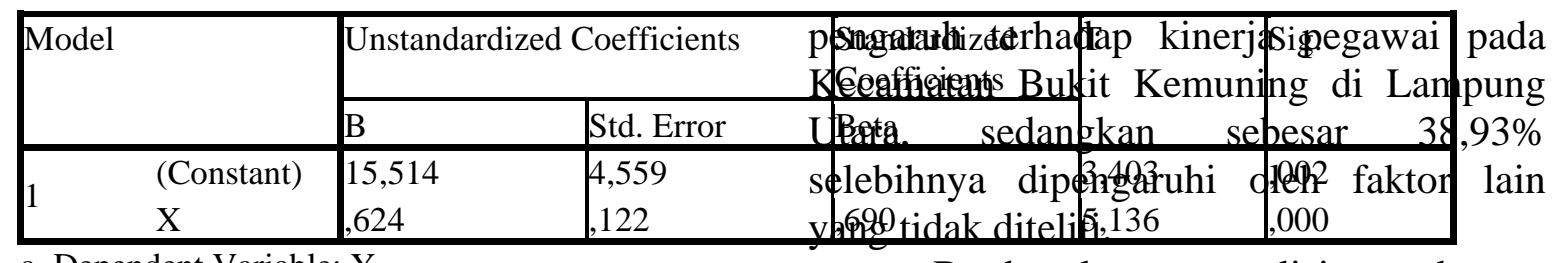

a. Dependent Variable: Y

Berdasarkan hasil Uji t didapat nilai thitung $=5,136$. Apabila dibandingkan dengan ttabel pada taraf signifikan yaitu 1,690 , maka thitung $=5,136>$ ttabel $=$ 1,690, sehingga dapat disimpulkan bahwa; Hipotesis yang menyatakan terdapat pengaruh antara Variabel Budaya Organisasi (X) terhadap Kinerja Pegawai (Y) pada Kecamatan Bukit Kemuning di Lampung Utara dapat diterima. Jadi variabel Budaya Organisasi berpengaruh terhadap variabel Kinerja Pegawai (Y) pada Kecamatan Bukit Kemuning di Lampung Utara.

\section{KESIMPULAN DAN SARAN}

\section{Kesimpulan}

Berdasarkan hasil penelitian dan pembahasan yang sudah dilakukan maka dapat disimpulkan sebagai berikut :

Nilai koefisiensi determinasi (R2) variabel budaya organisasi terhadap kinerja pegawai sebesar 0,6107. Hal ini menunjukkan bahwa pengaruh budaya organisasi terhadap kinerja pegawai sebesar $61,07 \%$ dan sisanya 38,93\% dipengaruhi oleh faktor lain. Dari analisis diperoleh koefisien korelasi atau $\mathrm{t}$ hitung $=5,136$ sedangkan $\mathrm{t}$ tabel dengan taraf signifikan 1,690 dengan demikian t hitung lebih besar dari $t$ table $5,136>1,690$. Hal ini menunjukkan budaya organisasi mempunyai hubungan yang signifikan terhadap kinerja.

Untuk mengetahui analisis tersebut, maka dapat diketahui dengan menggunakan koefisien penentu (r2) dengan nilai 61,07\%, dengan ini budaya organisasi mempunyai
Berdasarkan analisis dengan menggunakan Koefisien Determinasi (KD) berarti terdapat pengaruh yang positif dan signifikan antara budaya organisasi dengan kinerja pegawai pada Kecamatan Bukit Kemuning di Lampung Utara.

\section{Saran}

1. Hendaknya pegawai pada Kecamatan Bukit Kemuning di Lampung Utara lebih meningkatkan kinerjanya yang dapat memberikan yang terbaik dalam hal ini tentang budaya organisasi dalam bekerja.

2. Hendaknya pegawai pada Kecamatan Bukit Kemuning di Lampung Utara lebih meningkatkan lagi kinerjanya dengan cara menanamkan rasa memiliki lingkungan kerjanya dan rasa tanggung jawab terhadap tugas yang diberikan kepadanya.

\section{DAFTAR PUSTAKA}

Ambar Teguh Sulistiyani dan Rosidah, 2003, Manajemen Sumber Daya Manusia, Yogyakarta :Graha Ilmu

Anwar Prabu Mangkunegara (2006), Evaluasi Kinerja SDM. Jakarta: Eresco.

Arikunto, Suharsimi. 2002. Prosedur penelitian. Jakarta. Rineka Cipta.

Ashar Sunyoto. 2001 Psikologi Pegawai dan Organisasi. Jakarta : UIP

Davis, Keith (2005) Perilaku Organisasi. Jakarta :Salemba Empat 
Edwin B. Flippo. 2006. Manajemen Personalia Jilid I. Alih bahasa oleh Moh Masud, SH.,MA. Jakarta.Erlangga.

Ghozali Imam 2005, Aplikasi SPSS BP. Semarang : Universitas Diponegoro

Gibson James L, 2000 Perilaku Organisasi. Jakarta: Edisi ke 5 Erlangga

Handoko, T. Hani. 2000. Manajemen Personalia dan Manajemen Sumber Daya Manusia. Yogyakarta. BPFE-Yogyakarta.

Hasibuan, Malayu S.P..2000 .Manajemen Sumber Daya Manusia. Jakarta. Bumi Aksara.

Hasibuan, Malayu S.P..2006. Prestasi Kerja Pegawai. Jakarta. Bumi Aksara.

Kreitner dan Kinicki, 2008:79. Budaya Organisasi. Jakarta. Salemba empat

Mathis, Robert L \& John H. Jackson ( Terjemahan Jimmy Sadeli dan Bayu Prawira), 2001. Manajemen Sumber Daya Manusia, jilid I. Jakarta. Penerbit Salemba

Moekjizat 1995. Latihan dan Pengembangan Sumber Daya Manusia. Bandung :Bandar Maju 